\title{
АКТИВІЗАЦІЯ РОЗВИТКУ ПРИКОРДОННИХ ТЕРИТОРІЙ ЗАХІДНОЇ УКРАЇНИ ЗА ДОПОМОГОЮ ТРАНСКОРДОННОГО СПІВРОБІТНИЦТВА
}

\author{
Головка А. А.
}

\section{ВСТУП}

Зміцнення матеріальної та фінансової основи базового територіального рівня та розширення обсягу прав громад у розпорядженні наявними ресурсами - це закономірні наслідки реформи місцевого самоврядування та територіальної організації влади, які створюють передумови для активізації місцевого та регіонального розвитку. I не дивлячись на існування низки проблемних питань та ризиків, все ж практика свідчить про правильність вибраних в рамках реформи децентралізації пріоритетів.

Одним із шляхів досягнення цілей місцевого та регіонального розвитку в умовах нової територіальної організації влади є активізація транскордонного співробітництва. У цьому контексті йдеться про зміцнення економічних та гуманітарних зв'язків між українським прикордонням та суміжними регіонами країн $\mathrm{CC}$, міжтериторіальну кооперацію у вирішенні спільних проблем, впровадження спільних транскордонних проєктів та ініціатив для реалізації потенціалу до розвитку територій-партнерів. Можливим є досягнення синергетичного ефекту від використання транскордонного співробітництва та позитивних наслідків децентралізації.

Тим не менш, для використання прикордонними територіями свого географічного положення та транскордонних зв'язків як конкурентної переваги необхідним $\epsilon$ вирішення нагальних проблем у сфері транскордонного співробітництва. Це передбачає здійснення низки кроків із забезпечення транскордонної взаємодії на прозорих інклюзивних засадах, здійснення ефективної державної підтримки та сприяння досягненню територіальними громадами достатнього рівня конкурентоспроможності в «боротьбі за європейські фонди».

Представлений матеріал не містить детального опису усього спектру явищ та процесів в сфері транскордонного співробітництва. У ньому наданий огляд ситуації у цілому із виокремленням найбільш характерних особливостей розвитку транскордонних та міжтериторіальних відносин, а також виокремленими на цій основі пропозиціями («дороговказами») 
для органів державної влади та органів місцевого самоврядування. Географічні межі дослідження - прикордонні області Західної України, що межують із країнами СС (Закарпатська, Львівська, ІваноФранківська, Чернівецька та Волинська області).

\section{1. Транскордонне співробітництво для зміцнення спроможності до розвитку територіальних громад Західної України}

Географічна близькість Західної України до кордонів ЄС слугує важливим чинником забезпечення взаємовигідної транскордонної співпраці між прикордонними регіонами України та територіями сусідніх європейських країн. Для Закарпатської, Львівської, ІваноФранківської, Чернівецької та Волинської областей інструменти транскордонного співробітництва $\epsilon$ одним із рушіїв регіонального розвитку та важливим джерелом фінансових ресурсів (передусім в рамках міжнародної технічної допомоги). Окрім того, реформа місцевого самоврядування та територіальної організації влади в Україні створює передумови для посилення взаємодії територіальних громад із відповідними суб'єктами країн-сусідів в аспектах взаємокоординованого просторового планування, реалізації спільних проєктів та ініціатив, вирішення спільних проблем в економічній, гуманітарній, екологічній та інших сферах. Встановлення таких транскордонних зв'язків важливе у межах досягнення цілей євроінтеграції.

Разом зі тим, володіючи очевидними перевагами (включно географічною близькістю до кордонів (С), Західноукраїнські території «стикаються» із низкою проблем, що безпосередньо обумовлені їх географією:

1) значну частину території областей Західної України займають Карпатські гори. I поряд із очевидними позитивами (наявність природніх бальнеологічних та рекреаційних зон для розвитку туризму, можливості для розвитку сільського та гастрономічного туризму i т. д.) це має і негативні наслідки, а саме: низький рівень транспортної доступності високогірних населених пунктів, низький рівень розвитку інфраструктури та логістичні проблеми, підвищені ризики стихійних лих;

2) згадані проблеми накладаються на демографію, а саме високий відсоток сільського населення (в Закарпатській області - 62,9\% мешканців області проживають у сільській місцевості, в Чернівецькій $58,1 \%$, в Івано-Франківській - 58,3\%, в Волинській - близько $50 \%$, в Львівській - 39,3\%). Одним із наслідків згаданих вище факторів $\epsilon$ внутрішньорегіональні та міжрегіональні диспропорції у розвитку між гірськими та рівнинними територіями, процеси «занепаду села» і пов'язані із цим соціальні наслідки. Області Західної України (окрім Львівської області) сприймаються як депресивні та «хронічно» 
дотаційні. В цьому контексті слід розуміти, що вони володіють значним внутрішнім потенціалом до розвитку, який, втім, поки не розкритий в достатній мірі ${ }^{1}$;

3) значна за обсягами трудова міграція, яка здійснює істотний вплив на регіональну економіку через втрати людського капіталу (що включає в себе і процеси «відпливу» за кордон кваліфікованої робочої сили, наукових кадрів та молоді). Високий рівень трудової міграції пов'язаний, nо-перше, із описаними в попередньому пункті депресивності територій, по-друге, близькістю до кордонів значно розвиненіших країн, що характеризуються вищими показниками соціально-економічного розвитку (заробітна плата, можливості для розвитку людського потенціалу і т. д.), ніж українські прикордонні території².

Необхідність досягнення балансу в рамках такої непростої конфігурації географічних факторів $\epsilon$ довгостроковим пріоритетом як для обласних керівників так і для центральної влади (в особі Президента України, уряду та профільних міністерств). Транскордонне співробітництво, у цьому контексті, може виступати одним із інструментів досягнення такого балансу. Його доречно розглядати як один із «драйверів» розвитку регіону, що може посилити його конкурентні переваги (наприклад, для Західного регіону це може бути розвиток природних рекреаційних зон, збереження архітектурних та історико-культурних пам'яток як чинника реалізаиії туристичного потенціалу), забезпечити пошук і розкриття нових конкурентних переваг (зокрема посилення позитивного ефекту розширених бюджетних та управлінських можливостей громад).

Використання транскордонного співробітництва в рамках досягнення цілей місцевого та регіонального розвитку (1) сприятиме формуванню осередків економічної та соціальної в громадах, (2) слугуватиме для місцевих еліт, бізнесу та громадськості «з обидвох сторін кордону» наочним підтвердженням взаємозалежності їх прогресу - в умовах тісних транскордонних зв'язків підтримка розвитку українського прикордонного регіону / громади становитиме один із чинників розвитку сусідніх громади та регіону, i навпаки.

Відсутність або недостатні дії для налагодження горизонтальної кооперації між країнами-сусідами (членами СС) та прикордонними громадами Західної України означатиме для останніх невикористання

${ }^{1}$ Драйвери розвитку економіки Західного регіону України. Аналітична записка НІСД. URL : https://niss.gov.ua/doslidzhennya/regionalniy-rozvitok/drayveri-rozvitkuekonomiki-zakhidnogo-regionu-ukraini.

2 Драйвери розвитку економіки Західного регіону України. Аналітична записка НІСД. URL : https://niss.gov.ua/doslidzhennya/regionalniy-rozvitok/drayveri-rozvitkuekonomiki-zakhidnogo-regionu-ukraini. 
свого географічного положення як конкурентної переваги, а також нереалізованість потенціалу транскордонного співробітництва для цілей регіонального розвитку, а тому (з високою ймовірністю) збереження депресивності розвитку та внутрішньо- / міжрегіональних диспропорцій. До того ж неефективність транскордонного співробітництва обумовлює втрату прикордонними регіонами статусу надійних партнерів, що в довгостроковій перспективі загрожує формуванням в їх «європейських партнерів» хибного сприйняття Західноукраїнського прикордоння як «неперспективного» напрямку для встановлення довгострокових партнерських відносин.

Окремим суттєвим чинником розвитку громад на прикордонних територіях $\epsilon$ їх перебування в сфері дії програм транскордонного співробітництва (виділених в рамках Європейського інструменту сусідства) та макрорегіональних стратегій, що слугують «платформою» для співпраці із суміжними громадами сусідніх країн в рамках вирішення спільних проблем, а також становлять джерело залучення фінансових ресурсів. Таким чином, об'єднання зусиль суміжних громад щодо вирішення спільних проблем («сміттєва криза», екологічні проблеми, депресивність гірських територій Карпатського регіону i m.d.) дає можливість акумулювати ресурси зацікавлених сторін (включно залучати їх в рамках програм європейських фондів).

Наявність спільних проблем західноукраїнського прикордоння та сусідніх прикордонних регіонів СС впливає на внутрішньополітичні, економічні процеси та характер міждержавних відносин, але і спонукає до пошуку спільних рішень. Показовий приклад - характерні для Карпатського регіону асиметрії у розвитку гірських, передгірних та рівнинних територій (який включає в себе території (передусім України, Польщі, Словаччини, Угорщини та Румунії), свідчать про «згасання» драйверів розвитку Карпатського регіону (невикористання конкурентних переваг регіонів в рамках реалізації їх внутрішнього потенціалу до розвитку).

Отже, активізація транскордонного співробітництва може посилити позитивний ефект від розширення управлінських та бюджетних повноважень громад, а також дозволить у повному обсязі використовувати переваги від їх прикордонного географічного положення. Розвиток мережі транскордонних зв'язків та контактів, «інвентаризація» проблем та формування алгоритму дій для їх ліквідації сформує умови для взаємодії у пошуку та реалізації рушіїв розвитку прикордонних територій Західної України та сусідніх країн ЄC i, як наслідок, створить додаткові можливості досягнення цілей місцевого та регіонального розвитку. 


\section{2. Актуальні проблеми розвитку транскордонного співробітництва}

Незважаючи на високе значення транскордонного співробітництва у розвитку регіонів, важливо констатувати наявність системних недоліків державної політики за даним напрямком, які унеможливлюють його ефективне використання в межах регіонального розвитку:

1. Згортання державної підтримки транскордонного співробітництва - погоджуючись із висновками директорки Асоціації «Сврорегіон Карпати - Україна» Галини Литвин, варто підкреслити несистемність механізму співфінансування українською стороною проєктів транскордонного співробітництва. Зазвичай власний внесок в структурі бюджету транскордонного проєкту складає $10 \%$, ця частка забезпечується у межах коштів передбачених в місцевих бюджетах та, що дуже важливо, в державному бюджеті у вигляді субвенції. Однак в Україні наявна проблема недостатньої та несвоєчасної фінансової підтримки транскордонного співробітництва 3 боку держави, що підтвердив приклад 2019 року $^{3}$.

Тільки після тиску широкої коаліції зацікавлених сторін (передусім представників Асоціації «Сврорегіон Карпати - Україна», за підтримки окремих народних депутатів) урядом було затверджено субвенцію та іiі розподіл на реалізацію проєктів транскордонного співробітництва у розмірі 10 млн. грн. (при тому що необхідний обсяг складав 300 млн. грн.). Окрім того, фінансування із держбюджету було здійснено вже в кінці бюджетного року, що значно ускладнило освоєння коштів, а також стало одним із основних факторів відхилення пропозиції включення до проєкту Держбюджету на 2020 рік «Субвениіі з державного бюджету місиевим бюджетам на реалізаџію проектів транскордонного співробітнищтва» для Мінрегіону.

2. Потреба посилення спроможності украӥнських регіонів та громад конкурувати із зарубіжними суб'єктами (передусім країнами (C) у залученні ресурсів в рамках міжнародної технічної допомоги та реалізації транскордонних проєктів. Серед працівників органів місцевого самоврядування відчутним є дефіцит (або повна відсутність) компетенцій щодо ефективного проєктного менеджменту, оформлення заявок / аплікаційних форм, іншої необхідної документації, комунікації iз грантодавцями. До того ж варто підкреслити недостатність поінформованості місцевих громад та місцевого керівництва про можливості, які дає участь в транскордонному співробітництві, а також весь комплекс його механізмів та форм.

\footnotetext{
3 Литвин Г. Чи $є$ шанс на державну підтримку транскордонної співпраці не лише на папері?. Zaxid.Net. URL : https://zaxid.net/blogi_tag50977/.
} 
Ще одним важливим аспектом, який впливає на рівень конкурентоспроможності $\epsilon$ перешкоди на шляху використання податкових пільг. Відповідно до Рамкової угоди між Урядом України і Комісією Європейських Співтовариств (а саме пункту 3.3.) «Контракти, фінансовані коштом Європейського союзу, не підлягають сплаті податку на додану вартість...». Тим не менш, як справедливо підкреслює Г. Литвин, підрядники та субпідрядники українських партнерів проєктів стикаються із юридичними та процедурними перешкодами в ході підтвердження права на звільнення від ПДВ, що вимагає значних затрат часу та підготовки необхідної документації для фіскальних органів. При цьому у значній кількості випадків мають місце відмови на заяви щодо звільнення від сплати ПДВ. В умовах відсутності таких обмежень в суб'єктів з країн СС конкурентоспроможність українських учасників значно знижується ${ }^{4}$.

3. Проблеми розвитку єврорегіонів. Сврорегіон є найпоширенішою організаційною формою транскордонного співробітництва - в Україні, було створено десять єврорегіонів. На території Західної України локалізовані чотири єврорегіони (див. рис. 1) - «Карпатський» (створений 14.02.1993), «Буг» (29.09.1995), «Нижній Дунай» (14.08.1998), «Верхній Прут» (22.09.2000), «Дністер» (створений 02.02.2012).

У рамках даної наукової публікації не буде наводитись детальний та розгорнутий опис практики функціонування усіх згаданих єврорегіонів, але для наочного прикладу в даному матеріалі будуть розглянуті тільки загальні проблеми розвитку територіально найбільшого єврорегіону «Карпатський», який включає найбільшу кількість учасників (регіони чотирьох країн Євросоюзу та України) та має найтриваліший період функціонування (майже 28 років). Не дивлячись на значний потенціал розвитку транскордонного співробітництва в межах даного об'єднання доречно виділити низку факторів, що гальмують розвиток транскордонного, міжрегіонального партнерства в рамках єврорегіону «Карпатський».

Масштаб території єврорегіону «Карпатський» та велика кількість регіонів-учасників (див. таблицю 1) робить складним процес транскордонної співпраці на рівні усього єврорегіону. Зазвичай реалізація спільних ініціатив та проєктів між учасниками даного об’єднання здійснюється переважно у двосторонньому форматі. Різні системи адміністративно-територіального устрою та територіальної організації влади, що характерні для учасників єврорегіону «Карпатський»

\footnotetext{
${ }^{4}$ Литвин Г. Чи є шанс на державну підтримку транскордонної співпраці не лише на паперi?. Zaxid.Net. URL : https://zaxid.net/blogi_tag50977/.
} 
обумовлюють різні обсяги компетенції та управлінських повноважень. Це створює труднощі у визначенні аналогічних адміністративних одиниць 3 однаковими повноваженнями, особливо на місцевому рівні, в рамках яких могла б розвиватися співпраця 5

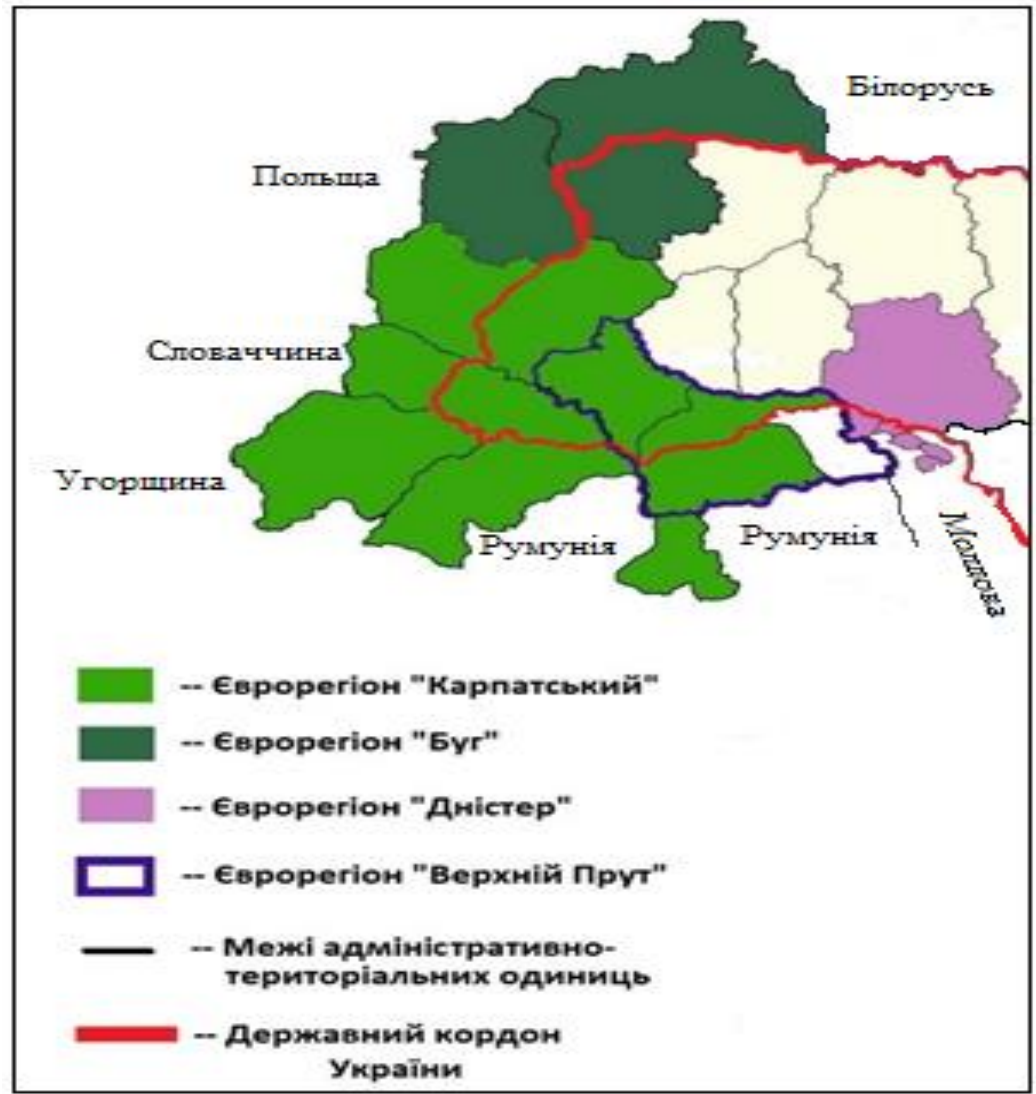

Рис. 1. Сврорегіони, які функціонують на території Західної України

5 Мателешко Ю. Головні аспекти і проблеми дослідження Карпатського Єврорегіону в українській науці. Науковий вісник Ужгородського університету: серія «Історія». 2013. Випуск 2(31), С. 177-183. 
Таблиця 1

Регіони-учасники Сврорегіону «Карпатський» ${ }^{6}$

\begin{tabular}{|l|c|c|}
\hline \multicolumn{1}{|c|}{ Назва регіону } & $\begin{array}{c}\text { Кількість } \\
\text { населення, } \\
\text { млн осіб }\end{array}$ & $\begin{array}{c}\text { Площа, } \\
\text { кв. км }\end{array}$ \\
\hline Підкарпатське воєводство (Польща) & 2,2 & 18683 \\
\hline $\begin{array}{l}\text { Повіти Біхор, Селаж, Сату-Маре, Марамуреш, } \\
\text { Харгіта, Сучава та Ботошань (Румунія) }\end{array}$ & 3,4 & 42308 \\
\hline $\begin{array}{l}\text { Кошицький та Прешовський краї (Словацька } \\
\text { Республіка) }\end{array}$ & 1,6 & 10459 \\
\hline $\begin{array}{l}\text { Медьє Боршод-Абауй-Земплен, Гайду-Бігар, } \\
\text { Гевеш, Яс-Надькун-Сольнок } \\
\text { та Саболч-Сатмар-Берег (Угорщина) }\end{array}$ & 2,6 & 28639 \\
\hline $\begin{array}{l}\text { Львівська, Івано-Франківська, } \\
\text { Закарпатська та Чернівецька області (Україна) }\end{array}$ & 6,3 & 56600 \\
\hline Загалом: & 16,1 & 156689 \\
\hline
\end{tabular}

4. Проблеми створення та розвитку європейських об'єднань територіального співробітництва (СОТС). В Україні можливість створення СОТС передбачено Законом України «Про транскордонне співробітництво» ${ }^{7}$. Питання, пов'язане зі створенням СОТС, було унормоване відповідно до Закону України 2515-VIII «Про внесення змін до деяких законів України щодо транскордонного співробітництва» від 04.09.2018, що, безумовно, $\epsilon$ сприятливим чинником в рамках активізації процесів транскордонного співробітництва. Саме після прийняття згаданих вище змін до законодавства фактично було створено необхідну правову основу для такого роду об'єднань. Сдиним прикладом практичного впровадження в Україні такої організаційної форми транскордонного співробітництва, як СОТС (станом на грудень 2020 р.) є утворене в рамках угоди між Закарпатською областю Украӥни та регіоном Саболч-Сатмар-Берег (Угорщина) об'єднання «ТИСА» (див. рис. 2).

Варто констатувати брак поінформованості громад щодо сутності ЄОТС, юридичного алгоритму їх створення та можливостей, які вони дають. Відсутніми є як методична підтримка громад (нема розроблених методичних рекомендацій щодо формування ЄОТС між суб'єктами транскордонного співробітництва України та відповідними

6 Аналітичний документ «Карпатський Горизонт 2013» - обгрунтування доцільності розробки та реалізації окремої операційної програми ЄС для регіону Карпат у наступній фінансовій перспективі. Веб-сайт Міжнародного Фонду «Відродження».

Статті 1 та 9, ЗУ «Про транскордонне співробітництво». URL : https://zakon.rada.gov.ua/laws/show/1861-15\#Text. 
суб'єктами країн (С), так і інформаційно-роз'яснювальна робота серед громад із залученням відповідних фахівців та експертів для представників міст, селищ і сіл та територіальних громад. До того ж значним недоліком $\epsilon$ невикористання на місцевому рівні практики організації ділових поїдок представників територіальних громад за кордон (в регіони, що мають досвід створення СОТС), з метою запозичення досвіду та вивчення даної організаційної форми транскордонного співробітництва «із середини».

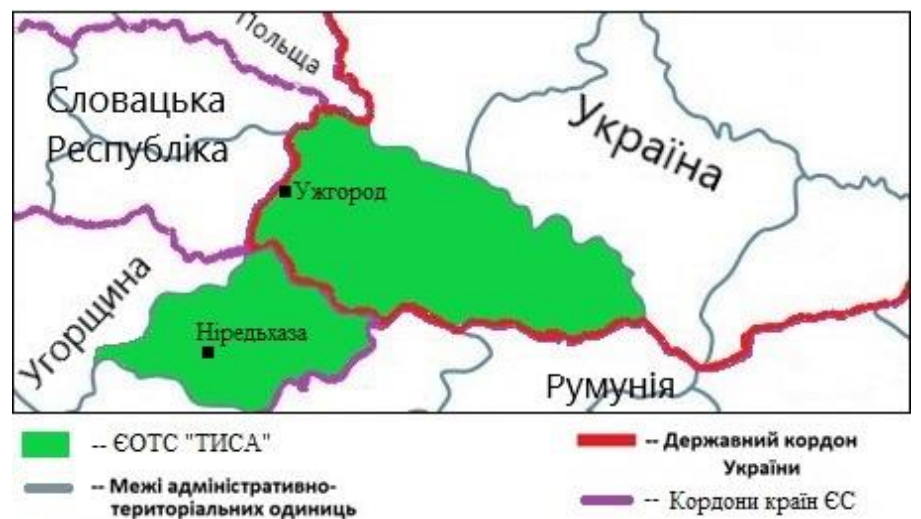

Рис. 2. Європейське об’єднання територіального співробітництва «ТИСА»

5. Інформаційний супровід. Окремою проблемою розвитку організаційних форм транскордонного співробітництва (характерно i для єврорегіонів і для (ОТС) у цілому $\epsilon$ недостатній рівень інтерактивно-інформаційного забезпечення та супроводу транскордонних об'єднань, ознаками чого є:

- низька частота оновлення веб-сайтів єврорегіонів / СОТС або їх відсутність;

- недостатня присутність інформаційної бази єврорегіонів / ЄОТС в соціальних мережах та невикористання можливостей поширення аудіовізуальних матеріалів на популярних відеохостингах (наприклад «YouTube»);

- низький рівень відображення в інформаційному просторі успішних кейсів та проєктів, що реалізовані в рамках єврорегіонів / ЄОТС, які б могли сприяти просуванню його позитивного іміджу та загалом популяризувати різні форми транскордонного співробітництва.

6. Проблеми невикористання потенціалу програм транскордонного i територіального співробітництва в рамках реалізації стратегій 
регіонального / місиевого розвитку. Використанню транскордонного співробітництва як дієвого інструменту регіонального розвитку перешкоджає відсутність уніфікованого підходу до відображення транскордонної складової у програмах та стратегіях регіонального (області) та місцевого (громади) розвитку, що звужує як можливості їх узгодження із Державною програмою розвитку транскордонного співробітництва на 2021-2027 pp. (після іiі затвердження), так і можливості реалізації конкурентних переваг пов'язаних із їх прикордонним положенням.

Відсутніми є інституційні засади для використання встановлених між прикордонними регіонами України та сусідніх країн $\mathrm{CC}$ горизонтальних зв'язків та контактів для регіонального розвитку: реалізації складових частин потенціалу розвитку прикордонних регіонів (можливостей для розвитку галузі туризму та рекреації регіону Українських Карпат, транзитного потенціалу), використання позитивного ефекту фінансової децентралізаиії (збільшення обсягів місцевих бюджетів) i т.д. Тому набуває важливого значення встановлення стійкого взаємозв'язку між стратегіями розвитку прикордонних регіонів та визначеними в програмах транскордонного та територіального співробітництва пріоритетами ${ }^{8}$.

Низький рівень узгодженості стратегій регіонального та місцевого розвитку із пріоритетами, визначеними в програмах транскордонного співробітництва, пов'язаний із відсутніми обов'язковими нормами щодо включення до стратегічних документів регіонального значення таких компонентів: (1) положення угод про транскордонне співробітництво між українськими адміністративно-територіальними одиницями та відповідними суб'єктами сусідніх країн; (2) пріоритетів, які визначені в операційних програмах транскордонного співробітництва (тих, які поширюються на українські регіони); (3) формування власних проєктів та їх просування серед «транскордонних партнерів». До того ж доречно констатувати, що відсутнім є і узгодження систем планування стратегій та програм розвитку із цілями, визначеними у Державній програмі транскордонного співробітництва 2021-2027 pp., а також сформована методологія оцінки взаємозв'язків та синергії між заходами та результатами, передбаченими даною програмою та регіональними, місцевими стратегіями і програмами розвитку.

\footnotetext{
${ }^{8}$ Синергія програм транскордонного співробітництва та стратегій регіонального розвитку в Україні. Аналітичний звіт. URL :_https://www.civic-synergy.org.ua/wpcontent/uploads/2018/04/Synergiya-program-transkordonnogo-spivrobitnytstva-tastrategij-regionalnogo-rozvytku-v-Ukrayini.pdf.
} 


\section{3. Напрями зміцнення «транскордонної суб'єктності» прикордонних регіонів та територіальних громад}

Використання розширених управлінських та бюджетних можливостей територіальних громад в контексті посилення їх участі в процесах транскордонного співробітництва, в коротко- та середньостроковій перспективі дозволять активізувати розвиток Західноукраїнських прикордонних територій; в довгостроковій створять умови для перетворення Західного регіону в провідника євроінтеграційних прагнень України та «європейських стандартів» в економіці, гуманітарній сфері, захисту екології, управлінні, господарстві, соціальних взаємовідносинах.

3 огляду на наявність практичного досвіду участі в ініціативах транскордонного співробітництва та мережі організацій і установ, які спеціалізуються на такій діяльності, можна говорити про можливості використання цього ресурсу як «драйвера» активізації усестороннього співробітництва між регіонами (передусім Західного регіону) України та $€$, особливо в умовах розширення управлінських та бюджетних можливостей місцевих громад в результаті децентралізації. Адміністративно-територіальна реформа створює можливості для залучення до транскордонної співпраці справжніх іiі суб’єктів територіальні громади.

Нова територіальна організація влади на засадах децентралізованого управління і субсидіарності дозволяє розширити можливості щодо створення локальних партнерств i кооперації між учасниками транскордонного співробітництва: агенціями регіонального розвитку, науково-дослідними інститутами та центрами, іншими підрозділами університетів, координаторами регіональних офісів міжнародних організацій (таких як «U-LEAD з Свропою», USAID та ін). Розширена кооперація сприяє утвердженню міжнародної суб'єктності територіальних громад завдяки залученню відповідних фахівців та експертів, забезпеченню фахового та консультативного супроводу та активізації співпраці між українськими громадами та відповідними суб'єктами сусідніх країн ЄС.

У межах посилення суб'єктності, ініціативності / залученості територіальних громад в процеси транскордонного співробітництва важливе значення має здійснення інформаційно-консультативних заходів, координація та супровід участі місцевих громад в конкурсах та програмах транскордонного співробітництва. Окрім того, істотну роль відіграє врахування при визначенні пріоритетів розвитку транскордонного співробітництва взаємопов'язаності цілей стимулювання міжнародної участі територіальних громад та забезпечення їх соціального та економічного добробуту (шляхом 
формування кластерних моделей як точок економічного розвитку територіальних громад, створення комфортних умов проживання для мешканців і т. д.).

В умовах нової територіальної організації влади органи виконавчої влади на обласному рівні спільно із агенціями регіонального розвитку, науковим та експертним середовищем зможуть стати, по-перше, «креаторами» стратегій та програм розвитку, по-друге, лобістами відображення транскордонної складової в згаданих документах, потретє, координаторами формування та просування ініціатив та проєктів транскордонного співробітництва направлених на активізацію місцевого та регіонального розвитку.

Такий вектор регіональної політики зумовлює активізацію координованих дій уряду, громад та локальних стейкхолдерів (місцевого бізнесу, агенцій регіонального розвитку, університетів, науково-дослідних установ) на наступних напрямках:

1. Забезпечення інклюзивності процесу транскордонного співробітництва - залучення до співпраці в межах транскордонного співробітництва широкого кола зацікавлених сторін: представників місцевого бізнесу, агенцій регіонального розвитку, університетів та інших освітніх закладів, науково-дослідних установ, місцевих експертів, науковців та волонтерів; інституціалізація партнерських відносин між ними.

Важливим є створення на рівні областей робочих груп 3 питань транскордонного співробітництва. До їх основних функцій доречно включити: заохочення громад, місцевого бізнесу, науковців до транскордонної співпраці із суміжними регіонами (за допомогою проведення циклу публічних заходів із залученням відповідних експертів, проведення інформаційних або навчальних турів в громади тощо); здійснення координації та супроводу участі територіальних громад в операційних програмах транскордонного та територіального співробітництва / грантових конкурсах від європейських фондів; створення умов для позиціонування місцевих / регіональних ініціатив, планів та проєктів на «ринку»; моніторинг потенційних партнерів та «донорів» (фондів, інвесторів, цільових програм $)^{9}$.

Необхідно запровадити щорічну практику розробки та подання на розгляд обласних рад планів розвитку транскордонних зв'язків між областю, місцевими громадами Західної України, з одного боку, та

${ }^{9}$ Програми транскордонного співробітництва як драйвер розвитку об'єднаних територіальних громад Західного прикордоння. Аналітична записка HICД. URL : https://niss.gov.ua/doslidzhennya/regionalniy-rozvitok/programitranskordonnogospivrobitnictva-yak-drayver-rozvitku. 
відповідними суб'єктами сусідніх держав-членів ЄC, 3 іншого, із визначеними цілями укладення угод про транскордонного співробітництва, розробки та практичного впровадження програм та стратегічних документів щодо питань, які становлять спільний інтерес учасників, узгодженням завдань щодо акумуляції наявних ресурсів, проведенням публічних комунікаційних заходів та заходів з реалізації необхідних ініціатив.

2. Посилення конкурентоспроможності місиевих громад у сфері транскордонного співробітництва иляхом проведення відповідної інформаційної роботи та створення можливостей для покращення компетенцій органів місцевого самоврядування щодо участі в транскордонному співробітництві: організація та проведення інформаційно-навчальних турів, семінарів та тренінгів; підготовка та впровадження он-лайн практикумів, а також створення масових відкритих он-лайн курсів на найбільш розвинених платформах (наприклад «Prometeus», «Google Classroom»).

У даному випадку важливо звернути увагу на роль Агенцій регіонального розвитку. У рамках своєї роботи агенції можуть здійснювати: консультаційну та роз'яснювальну роботу щодо участі в програмах транскордонного співробітництва - підготовки необхідної документації, заявок та аплікаційних форм, кошторису i т. Д.; проєктний менеджмент - підготовка проєктів та їх подача для участі в тому чи іншому конкурсі / програмі.

Важливе значення має $\mathrm{i}$ забезпечення державної підтримки транскордонного співробітництва - для цього необхідно визначити серед трансфертів, які надаються із Державного бюджету субвенцію місцевим бюджетам на підтримку проєктів транскордонного співробітництва. Це передбачає внесення відповідних змін до Бюджетного кодексу України. Після здійснення зазначених нормативних змін, важливо забезпечити врахування даного трансферту при розробці проєктів Державного бюджету України на наступні бюджетні періоди ${ }^{10}$.

3. Сприяння розвитку транскордонного співробітництва в науковій та технологічній сферах. В умовах реформи місцевого самоврядування та територіальної організації влади в Україні важливе значення має посилення залученості усіх зацікавлених сторін (стейкхолдерів) у процес вирішення проблем розвитку громад та регіону у цілому, що

\footnotetext{
${ }^{10}$ Програми транскордонного співробітництва як драйвер розвитку об'єднаних територіальних громад Західного прикордоння. Аналітична записка HICД. URL : https://niss.gov.ua/doslidzhennya/regionalniy-rozvitok/programitranskordonnogospivrobitnictva-yak-drayver-rozvitku.
} 
сприяє зростанню рівня згуртованості спільноти, зміцнення локальної ідентичності бізнесу та посилення його соціальної відповідальності. Особливо важливим є досягнення необхідного рівня взаємодії між владними інституціями, бізнесом, науковими та освітніми установами. 3 огляду на це досягнення інклюзивної діяльності громад можливо під час реалізації відповідних дій на наступних напрямках:

3а. Створення міжнародних консорціумів університетів та науководослідних установ - форма транскордонного співробітництва між університетами, науково-дослідними установами України та країни (країн) $\mathrm{CC}$, які локалізовані на прикордонній території в межах освітньої мобільності, наукового туризму, комерціалізації науки, розробки та впровадження наукових розробок та інновацій, міжкультурної взаємодії, які не суперечать законодавству та ратифікованим міжнародним договорам України та країни-учасниці (країн-учасників) консорціуму.

До того ж відповідний досвід в Західноукраїнських ВНЗ уже $\epsilon-$ iз ініціативи керівництва ДВНЗ «Ужгородський національний університет» в квітні 2015 року було засновано Міжнародний консорціум університетів, що об'єднує українські та європейські ВУЗи, a одним із основних пріоритетів діяльності консорціуму було визначено розробку спільних наукових та освітніх проєктів в рамках різних програм фінансування («Interreg Europe», «Visegrad Fund», «European Cooperationin Science and Technology», «Europe Aid», «Erasmus $+»)^{11}$.

3б. Створення нової краудфандингової платформи (або використання вже існуючих) як форми громадського фінансування (об’єднання наявних в громадян коштів та добровільні пожертви) соціально значимих проєктів та ініціатив. Краудфандинг може стати одним із інструментів для мобілізації необхідних ресурсів для фінансування стартап-проєктів, ініціатив у сфері соціального підприємництва.

3в. Створення загальноуніверситетських фондів (кошти яких можуть формуватися за рахунок міжнародної технічної допомоги, за рахунок внесків приватних та міжнародних донорів) для фінансування створення необхідної інфраструктури (лабораторій, приміщень та обладнання) для функціонування спеціалізованих форм взаємодії «наука-освіта-бізнес» та для проведення досліджень, доведення їх результатів та наукових розробок до рівня, придатного для комерціалізації.

\footnotetext{
11 Веб-сайт Міжнародного консорціуму університетів. URL : https://www.uzhnu.edu.ua/uk/consortium/.
} 
4. Сприяння створенню та розвитку СОТС. Як уже було згадано вище, в рамках транскордонного співробітництва все ще нереалізований потенціал СОТС в рамках зміцнення економічних та гуманітарних зв'язків між суміжними громадами, що локалізовані в транскордонній зоні. Концентрація зусиль органів виконавчої влади та територіальних громад саме на цьому напрямку потенційно може покращити функціонування великих за площею та кількістю населення єврорегіонів (наприклад єврорегіон «Карпатський»).

Також використання СОТС вирішуватиме низку завдань регіонального / місцевого розвитку: пожвавлення економічної кооперація та активізація інвестиційної діяльності, спільні дії із захисту навколишнього середовища (україно-угорська співпраця по протидії засміченню річки Тиса в Закарпатті), зміцнення міжкультурних зв'язків (наприклад зв'язків національних меншин із країнами свого походження в Закарпатській та Чернівецькій областях).

У рамках сприяння розвитку СОТС варто здійснити відповідні нормативні та організаційні кроки. Перш за все, доречною є розробка та впровадження методичних рекомендацій щодо процесу створення ЄОТС. Важливе значення має також розробка перспективних планів створення СОTC на прикордонних територіях України та країн $\mathrm{CC}$, з урахуванням попередніх консультацій та узгодження 3 представниками сусідніх країн $\mathrm{CC}$, з метою зміцнення економічних, гуманітарних, культурних зв'язків між ними, реалізації спільного просторового планування та ефективного проєктного менеджменту. Процес розробки перспективних планів створення СОТС необхідно проводити на рівні облдержадміністрацій (а саме їх структурних підрозділів, до сфери компетенції яких відносяться питання зовнішньоекономічних зв'язків, інвестицій та транскордонного співробітництва) при задіянні органів місцевого самоврядування та експертів.

5. Узгодженість та взаємодоповнення процесів транскордонного співробітництва та регіонального / місиевого стратегування. Зростаюча роль громад у процесі прийняття управлінських рішень щодо місцевого розвитку (включно транскордонного співробітництва) обумовлює необхідність гармонізації процесу стратегування регіонального / місцевого розвитку. Як уже було згадано наявною $\epsilon$ низькі сумісність і взаємодоповнення регіональних та місцевих стратегій розвитку із програмами транскордонного та територіального співробітництва (в частині організаційних, фінансових та інших пріоритетів). Для ефективного використання потенціалу програм транскордонного i територіального співробітництва в контексті регіонального та місцевого розвитку необхідними є: 
- встановлення обов'язковості узгодження регіональних, місцевих стратегій розвитку із Державною програмою розвитку транскордонного співробітництва на 2021-2027 роки (після ії затвердження).

- формування механізму узгодження системи планування регіональних, місцевих стратегій розвитку із пріоритетами та цілями розвитку єврорегіонів, СОТС, та інших організаційних форм транскордонного співробітництва визначених в двосторонніх або багатосторонніх угодах про транскордонне співробітництво.

\section{ВИСНОВКИ}

Регіони, які включені в процеси транскордонного співробітництва, володіють додатковими можливостями досягнення оперативних та стратегічних цілей розвитку в економічній, гуманітарній та інших сферах. Це пов'язано з можливостями (1) залучення додаткових коштів у рамках програм транскордонного та територіального співробітництва, (2) обміну досвідом, консультацій та взаємодії між підприємствами, органами влади / місцевого самоврядування, організаціями громадянського суспільства «по обидва боки кордону», (3) координованого співробітництва із регіонами країн СС у вирішенні спільних проблем (управління кордонами, забезпечення екологічної безпеки).

Утім, варто констатувати наявність низки чинників, які «гальмують» розвиток транскордонного співробітництва. Насамперед це неінклюзивність - низький рівень залученості локальних стейкхолдерів, а тому незадіяним є значний кадровий та інтелектуальний потенціал регіонів. Ще одним наслідком неінклюзивності $є$ зростання рівня скептичних настроїв громад та місцевого бізнесу щодо можливості використання транскордонного співробітництва в якості інструменту економічного та гуманітарного розвитку. До цього можна додати також недостатність компетенцій у сфері транскордонного співробітництва обраних на місцевих виборах 2020 р. депутатів місцевих рад та негативну тенденцію до згортання державної підтримки транскордонних проєктів в аспекті співфінансування. Це продовжує спроможність територіальних громад вести ефективну конкуренцію в рамках європейських програм та конкурсів.

Зараз важливим $\epsilon$ прийняття та впровадження рішень, які направлені на сприяння активізації транскордонного співробітництва та посилення суб'єктності територіальних громад у ньому, а саме:

- забезпечення інклюзивності у сфері транскордонного співробітництва;

- узгодження цілей розвитку єврорегіонів, СОТС із місцевими та регіональними стратегіями та програмами розвитку. Узгодження 
місцевих та регіональних стратегій та програм розвитку із цілями визначеними у Державній програмі розвитку транскордонного співробітництва на 2021-2027 (після затвердження останньої) для досягнення синергетичного ефекту від їх впровадження;

- забезпечення достатнього рівня державної фінансової підтримки транскордонного співробітництва;

- посилення конкурентоспроможності та ініціативності територіальних громад у рамках транскордонних проєктів та ініціатив.

\section{АНОТАЦІЯ}

Представлено погляд автора на можливості використання транскордонного співробітництва як інструменту активізації місцевого та регіонального розвитку в умовах нової територіальної організації влади. У фокусі уваги були потенційні напрямки співробітництва регіонів та громад Західної України із суміжними прикордонними регіонами країн $\mathrm{CC}$, а саме: кооперація та мобілізація ресурсів для вирішення спільних проблем, використання наявних і пошук нових можливостей для розвитку мережі економічних та гуманітарних зв'язків між підприємствами, місцевими органами влади та неурядовими організаціями.

Виокремлено та описано актуальні проблеми, що перешкоджають ефективному використанню транскордонного співробітництва в рамках досягнення цілей місцевого та регіонального розвитку. Запропоновано інструменти стимулювання та координації участі територіальних громад у транскордонних проєктах та ініціативах, активізації взаємодії між територіальними громадами та регіональними стейкхолдерами в рамках транскордонного співробітництва, оптимізації механізму співфінансування транскордонних ініціатив та проєктів. Зазначені пропозиції дозволять підвищити компетенції працівників органів місцевого самоврядування щодо застосування можливостей та форм транскордонного співробітництва; вдосконалити механізм співфінансування транскордонних ініціатив та проєктів; забезпечити інклюзивність процесу транскордонного співробітництва.

\section{ЛITЕРАТУРА}

1. Аналітичний документ «Карпатський Горизонт 2013» обгрунтування доцільності розробки та реалізації окремої операційної програми ЄС для регіону Карпат у наступній фінансовій перспективі. Веб-сайт Міжнародного Фонду «Відродження». URL : https://www.irf.ua/deputatam_evroparlamentu_prezentuvali_kontseptsiyu_roz vitku_karpatskogo_evroregionu/files/ukr/programs/euro/carpathian_full.pdfhtt 
ps://www.irf.ua/deputatam_evroparlamentu_prezentuvali_kontseptsiyu_rozvit ku_karpatskogo_evroregionu/files/ukr/programs/euro/carpathian_full.pdf.

2. Веб-сайт Міжнародного консорціуму університетів. URL : https://www.uzhnu.edu.ua/uk/consortium/.

3. Головка А. Розкриття потенціалу прикордонного регіону та протидія актуальним ризикам в умовах розширених можливостей місцевого самоврядування (на прикладі Закарпаття). Система державного управління в контексті децентралізаиії влади: Колективна монографія. Рига : Izdevnieciba «Baltija Publishing», 2020. С. 34-49.

4. Драйвери розвитку економіки Західного регіону України. Аналітична записка НICД. URL : https://niss.gov.ua/doslidzhennya/ regionalniy-rozvitok/drayveri-rozvitku-ekonomiki-zakhidnogo-regionuukraini.

5. Закон України «Про транскордонне співробітництво». URL : https://zakon.rada.gov.ua/laws/show/1861-15\#Text.

6. Литвин Г. Чи $є$ шанс на державну підтримку транскордонної співпраці не лише на папері? Zaxid.Net. URL : https://zaxid.net/blogi_tag50977/.

7. Мателешко Ю. Головні аспекти і проблеми дослідження Карпатського Єврорегіону в українській науці. Науковий вісник Ужсгородського університету: серія «Історія». 2013. Випуск 2(31). C. $177-183$.

8. Програми транскордонного співробітництва як драйвер розвитку об'єднаних територіальних громад Західного прикордоння. Аналітична записка НICД. URL : https://niss.gov.ua/doslidzhennya/regionalniyrozvitok/programitranskordonnogo-spivrobitnictva-yak-drayver-rozvitku.

9. Програми транскордонного співробітництва як драйвер розвитку об'єднаних територіальних громад Західного прикордоння. Аналітична записка НІСД. URL : https://niss.gov.ua/doslidzhennya/regionalniyrozvitok/programitranskordonnogo-spivrobitnictva-yak-drayver-rozvitku.

10. Синергія програм транскордонного співробітництва та стратегій регіонального розвитку в Україні. Аналітичний звіт. URL :_https://www.civic-synergy.org.ua/wp-content/uploads/2018/04/Synergiyaprogram-transkordonnogo-spivrobitnytstva-ta-strategij-regionalnogorozvytku-v-Ukrayini.pdf.

Information about the author: Holovka A. A., $\mathrm{PhD}$ in Political Science, Consultant National Institute for Strategic Studies 7-A, Pyrohova str., Kyiv, 01030, Ukraine 